\title{
The Nuremberg Trials and American Jurisprudence: The Decline of Legal Realism, the Revival of Natural Law, and the Development of Legal Process Theory
}

\author{
Rodger D. Citron"
}

\section{Introduction}

More than sixty years ago, the most important trial of the twentieth century-the first Nuremberg war crimes trial of the leaders of Nazi Germanybegan. As time has shown, the Nuremberg trials have significantly influenced the way we think about the rule of law. The literature on the Nuremberg trials is vast. It includes the accounts of the trials written by the lawyers who participated. ${ }^{1}$ It explores the central role of the Nuremberg trials in developing human rights law after World War II. ${ }^{2}$ And it covers a number of other important legal subjects. ${ }^{3}$ In this article, I will discuss the influence of the Nuremberg trials on legal philosophy in the Unit-

* I wish to thank Dean Lawrence Raful, Andrea Cohen, Dan Derby, Alan Hornstein, Beth Mobley, and April Schwartz for their time and assistance, Robert S. Summers for providing a prompt response to a request for more information about Lon Fuller, and Albert Messina for valuable research assistance. Needless to say, they are not responsible for any errors. This article was first published in the Michigan State Law Review 2006, 385-410. An earlier version of this paper was first presented at the Touro Law Center Conference, "Judging Nuremberg: The Laws, the Rallies, the Trials," in 2005.

1 See, e.g., Telford Taylor, The Anatomy of the Nuremberg Trials: A Personal Memoir (New York: Knopf, 1992). Jonathan Bush has described Taylor's book as "the best single account of the international Nuremberg trial." Jonathan A. Bush, "Nuremberg: The Modern Law of War and its Limitations," Columbia Law Review 93 (1993), 2024.

2 See, e.g., Matthew Lippman, "Nuremberg: Forty Five Years Later,", Connecticut Journal of International Law 7 (1991). As Professor Lippman has observed: "The post-World War II human rights movement was motivated in part by a desire to ensure that there would be no repetition of the type of atrocities and abuses which were committed by the German regime, as well as by a pragmatic concern that abuses of state power inevitably would lead to internal strife and renewed international instability." (51).

3 For example, Jonathan Turley has examined the Nuremberg trials as an example of "transformative justice." See Jonathan Turley, "Transformative Justice and the 
ed States, focusing on the decline of legal realism as an autonomous jurisprudential movement, the revival of natural law philosophy, and the emergence of legal process theory.

To understand fully the significance of the Nuremberg trials on American legal thought, it is necessary to first provide a sketch of American legal thought before World War II and the subsequent trials. The most intriguing-though not accepted-jurisprudential development in the decade before World War II was legal realism. Legal realism emerged in the late 1920s as a jurisprudential movement that criticized the formalist approach to law, expressed skepticism about the influence of the rules of law, and sought to demystify how courts operated and judges made decisions. The legal realists generally urged the incorporation of social science into efforts to understand how courts operated and to improve their operations.

The legal realists were viewed as intellectual provocateurs. By the early 1930s, legal realism had become a prominent jurisprudential movementnot dominant, but extensively discussed. Critics complained that the legal realists divorced morality from law, worshipped at the altar of power, and were engaged in a fruitless quest to impose the precision of scientific methods on the understanding of law and the legal system. As the decade progressed, the emergence of fascism abroad gave these criticisms additional urgency. In the aftermath of World War II, the horrors of Nazi Germany and the emerging totalitarian threat of the Soviet Union contributed to the decline of legal realism as an independent jurisprudential movement.

Two competing legal philosophies emerged as legal realism declined, and both can be understood, in large part, as responses to totalitarianism. The principal response, as Edward Purcell and Richard Primus have argued, was the revival of natural law. ${ }^{4}$ Natural law philosophy, broadly speaking, insists that positive law-statutes, and court decisions interpret-

Ethos of Nuremberg," Loyola of Los Angeles Law Review 33 (2000), 659 (describing the Nuremberg trials as "the trial of the century" and arguing that Nuremberg is a "symbol of our own potential for justice"). Other scholars have explored the influence of the Nuremberg trials on the jurisprudence of Justice Robert Jackson-who served as the lead prosecutor in the first trial-after he returned to the Supreme Court. See, e.g., Jeffrey D. Hockett, New Deal Justice: The Constitutional Jurisprudence of Hugo L. Black, Felix Frankfurter, and Robert H. Jackson (Lanham, MD: Rowman \& Littlefield Publishers, 1996), 267-281 (discussing the influence of the Nuremberg experience on Justice Jackson's First Amendment jurisprudence).

4 See Edward A. Purcell, The Crisis of Democratic Theory: Scientific Naturalism and the Problem of Value ([Lexington]: University Press of Kentucky, 1973), 75; Richard Primus, "A Brooding Omnipresence: Totalitarianism in Postwar Constitutional Thought," Yale Law Journal 106 (1996), 423, 427. 
ing statutes-should be evaluated according to a higher moral law. ${ }^{5}$ After World War II, the United States could no longer embrace a legal philosophy in which morality was detached from the legal system. The other response was the development of legal process theory. The "Legal Process School," as Bruce Ackerman has termed it, was concerned with the institutional structure of government, and emphasized that judges often should defer to the policy choices made by other governmental actors in deciding cases. ${ }^{6}$ This more limited understanding of the judicial role followed from the same concerns over totalitarianism and for democracy.

The topic of this article is enormously broad and spans nearly three decades. Therefore, at the outset, I have taken the following steps to make the topic more manageable.

First, my discussion focuses on three authors: Jerome Frank, Lon Fuller, and Herbert Wechsler. Each man is, deservedly, a towering figure in American jurisprudence. Frank, a New Deal lawyer and, later, a judge on the Second Circuit Court of Appeals, was the author of Law and the Modern Mind, a leading legal realist text. Fuller, a lifelong academic (primarily at Harvard Law School), was a perceptive critic of positivism and championed a secular natural law theory. Wechsler-the only author discussed in this article to have served at the Nuremberg trials, as an advisor to one of the judges on the tribunal from the United States-was a leading figure in the legal process school as it developed in the 1950s.

Second, in order to discuss the relevance of the Nuremberg trials to the development of American jurisprudence, it is necessary to situate the trials in historical and intellectual context. The trials loomed large in world politics during and after World War II, and inspired an extensive debate over

5 To put it another way, natural law also, generally, insists upon the existence of foundational principles of morality that exist apart from the legal rights and duties established by positive law. Natural law philosophy may be defined in relation to the legal philosophy of positivism. See, e.g., Philip Soper, "Some Natural Confusions about Natural Law," Michigan Law Review 90 (1992), 2393, 2395 (noting that, as a "legal theory," natural law "takes its shape from its explicit opposition to legal positivism"); see also infra notes 18-20 and accompanying text.

6 Bruce A. Ackerman, "Law and the Modern Mind," Daedalus 119 (1974), 123 (book review). Ackerman coined the phrase "Legal Process School" to refer to the legal academics who argued that "[s]ound legal decision-making ... was not simply a product of psychological maturity" and that the judge "had an obligation to use only those modes of reasoning 'appropriate' to the judicial role." Ibid. at 123 and note 26 . 
their legitimacy. ${ }^{7}$ The Nuremberg trials received extensive press coverage, and widely publicized the nature and extent of the Nazi atrocities during World War II. In addition, the trials were a significant event for legal philosophers. The trials both reflected and contributed to serious post-war concerns about totalitarianism. The debate inspired by the Nuremberg trials, therefore, is one measure of a broader shift in American legal thought, in which legal realism continued to decline as an autonomous jurisprudential movement, natural law philosophy returned to prominence, and legal process jurisprudence emerged.

Part I of the article provides a brief overview of legal realism situating it in relationship to legal formalism, and to positivism and natural law. Part II discusses Jerome Frank, his book Law and the Modern Mind, and the legal realism jurisprudential movement. It then considers criticism of both the book and the movement. Part III examines the influence of events following World War II-in particular, the Nuremberg trials, and more generally, the fear of fascism and concern for democracy inspired by the example of Nazi Germany-on Frank and Fuller, including the revival of natural law. Part IV, likewise, examines the influence of the Nuremberg trials on the development of legal process theory through the example of Herbert Wechsler, focusing on his famous "Neutral Principles" article. Part V concludes with a brief discussion of jurisprudential developments outside the academy, focusing on the Supreme Court's decision in Brown v. Board of Education ${ }^{8}$ as a leading example of the influence of Nazi Germany on post-war case law and legal thought.

\section{Situating American Legal Realism}

\section{A. The Emergence of Legal Realism as a Response to Formalism}

Legal realism in the United States emerged early in the twentieth century as a response to the dominance of formalism in legal thought and practice. Harvard Law School Dean Christopher Columbus Langdell, who devised a new approach to legal education in the 1870 s, is perhaps the archetypal le-

7 See, e.g., Primus, “A Brooding Omnipresence," 430 note 50 (collecting articles); see also Hans Kelsen, "The Rule Against Ex Post Facto Laws and the Prosecution of the Axis War Criminals," Judge Advocate Journal 8 (1945); Bernard D. Meltzer, Comment, "A Note on Some Aspects of the Nuremberg Debate," University of Chicago Law Review 14 (1947), 455.

8347 U.S. 483 (1954). 
gal formalist of this era. ${ }^{9}$ Langdell maintained that law is an inductive science, and "that all the available materials of the science are contained in printed books" of judicial opinions. ${ }^{10}$ For Langdell, as Professor Ackerman has explained, "the task of the legal scholar, like that of the natural scientist, was to transform the disordered data found in judicial opinions and render them intelligible by demonstrating the way in which each decision could be explained in terms of the fundamental legal principles implicit in the Common law."11

Oliver Wendell Holmes, Jr. was an early critic of legal formalism. Although Holmes respected Langdell's contribution to legal education, he disagreed with Langdell on the idea that logic was vital to the development of legal thought. ${ }^{12}$ In his 1881 book The Common Law, Holmes essentially "argued that practical expedients, necessitated by the needs and conflicts of human society, were more central to the development of law than were any logical propositions." ${ }^{13}$ Furthermore, Holmes maintained a skeptical attitude toward the law, defining it as nothing more than "the incidence of the public force through the instrumentality of the courts." ${ }^{14}$ By early in the twentieth century, Holmes's criticism of Langdell and legal formalism began to attract followers, planting the seeds that would develop into the legal realism movement. ${ }^{15}$

9 See Thomas Grey, "Langdell's Orthodoxy," University of Pittsburgh Law Review 45 (1983), 11-12 (Langdell's "orthodoxy" was "doubly formal" because, first, "the specific rules were framed in such terms that decisions followed from them uncontroversially when they were applied to readily ascertainable facts," and, second, "one could derive the rules themselves analytically from the principles.").

10 Christopher Columbus Langdell, in "Record of the Commemoration, November Fifth to Eighth, 1886, on the Two Hundred and Fiftieth Anniversary of the Founding of Harvard College" (1887), quoted in Ackerman, "Law and the Modern Mind," 126 note 3.

11 Ackerman, "Law and the Modern Mind," 119-120.

12 See Neil Duxbury, Patterns of American Jurisprudence (New York: Oxford University Press, 1995), 37.

13 Purcell, The Crisis of Democratic Theory, 75 (discussing Oliver Wendell Holmes, Jr., The Common Law [1881]).

14 Oliver Wendell Holmes, "The Path of the Law," Harvard Law Review 10 (1897), 457.

15 See Ackerman, "Law and the Modern Mind," 121 (identifying the first generation, including Holmes and James Bradley Thayer, as critics denying "the assumption of the scientific school that the Common Law had a fundamental structure discernible by the architectonic intelligence"; the second generation as "affected by Progressive politics and Deweyite pragmatism,” including Louis Brandeis, Felix Frankfurter, and Roscoe Pound; and the third generation of legal realists, including Frank). 
Holmes's legal philosophy loomed large in the work of Jerome Frank and other legal realists, who shared Holmes's skepticism of Langdell's formalism. They focused their efforts on investigating and explaining how judicial decisions really were made, and "attempted to move beyond the talk of rules and principles heard in the courtroom and the academy and to expose them as myths obscuring most of the principal factors at work in the decision-making process." 16 The idea of science figured prominently in the efforts of the realists, but it was not the self-contained, inductive logic of Langdell. Instead, the realists were dogged empiricists who consulted the social sciences-Frank, for example, turned to psychiatry-to locate the extra-legal factors that, they argued, determined the outcome of judicial decisions.

\section{B. Positivism, Natural Law, and Legal Realism}

In order to situate realism in relation to positivism and natural law, it is necessary to elaborate, albeit briefly, on the description of those philosophies. Positivism may be defined in relation to natural law, because natural law is-essentially-the opposite of positivism. As Professor Philip Soper has explained: "[T]he legal positivist claims that no necessary connection exists between law and morality; the natural law legal theorist denies that a sharp separation of these concepts is possible." ${ }^{17}$ A.P. d'Entrèves, a leading natural law philosopher, has elaborated:

$[T]$ he very assertion of natural law is an assertion that law is a part of ethics, [and] its essential function can appear only as that of mediating between the moral sphere and the sphere of law proper.... Perhaps the best description of natural law is that it provides a name for the point of intersection between law and morals. ${ }^{18}$

16 Ackerman, "Law and the Modern Mind," 121.

17 Soper, "Some Natural Confusions about Natural Law," 2395. The positivist view that law and morality are distinct is known as the separability thesis. See e.g., Anthony Sebok, Legal Positivism in American Jurisprudence (New York: Cambridge University Press, 1998), 30.

18 A. P. d'Entreves, The Natural Law (1951), quoted in Lloyd L. Weinreb, "Law as Order," Harvard Law Review 91 (1978), 909 note 1. Historically, the origins of natural law may be traced to works by, among others, Plato and Aristotle, Cicero, and Justinian's Corpus Juris, "and an elaborate theory of natural law was developed in the thirteenth century by Saint Thomas Aquinas." Henry Mather, "Natural Law and Liberalism," South Carolina Law Review 52 (2001), 332. 
Positivism emerged as a response to natural law in the nineteenth century. Historically, under positivism, the focus was not on the content of a law but instead on its pedigree.

Holmes displayed certain positivist tendencies in his jurisprudence. For example, he rejected the natural law notion of the common law as "a brooding omnipresence in the sky" and tended to defer to legislative enactments when they were challenged in court. ${ }^{19}$ There is much more to the definitions of natural law and positivism but, for present purposes, it is necessary to note only that natural law is defined by its concern for morality in law, while positivism is defined by its effort to separate morality from law.

Professor Fuller, as I discuss below, viewed American legal realism as a form of positivism. Although this understanding is not entirely agreed upon by legal philosophers, it is helpful to note the commonalities between realism and positivism. For example, both philosophies distrust the notion that there are certain superior principles of natural law-positivism because the assertion of natural law allows unwritten moral principles to trump actual positive law, and realism because the vagueness of general moral principles does not provide any guidance on how a court may decide a case. With positivism, the inquiry is limited to whether a pronouncement is a valid law. Positivism directs attention to the legislature, which has the authority to repeal existing statutes or to adopt new laws. ${ }^{20}$ Positivism binds the judge, who is limited to saying what the law is. Although American legal realists minimized the importance of rules, they shared with positivism an emphasis on description.

\section{Jerome Frank, Law and the Modern Mind, and Legal Realism}

To simplify matters, I will explain legal realism through the writings of Jerome Frank. Frank practiced corporate law in Chicago and New York City, held a number of high-level positions in the federal government dur-

19 Black \& White Taxicab \& Transfer Co. v. Brown \& Yellow Taxicab \& Transfer Co., 276 U.S. 518, 533 (1928) (Holmes, J., dissenting); Louise Weinberg, "Holmes' Failure," Michigan Law Review 96 (1997), 697 ("We remember Holmes' Supreme Court years for his deference to the political branches, his fatalism in the face of political will.").

20 Lon L. Fuller, The Law in Quest of Itself (Chicago: The Foundation Press, 1940), 131 ("A tacitly accepted philosophy of positivism seems to me also to underlie the modern preference for legislation as a means of legal reform.”). 
ing the New Deal (including Chairman of the Securities and Exchange Commission), and was appointed to the Second Circuit Court of Appeals in 1941. He wrote a number of books, including Law and the Modern Mind - a provocative and popular legal realist tract-and taught at Yale Law School. Frank was, to be sure, a committed legal realist. ${ }^{21}$

Frank offered a comprehensive critique of formalist legal thought. His views made him an extreme-and extremely clear-spoken-legal realist. In addition, Frank's views were well-known outside the legal academy. His first book, Law and the Modern Mind, sold well when it initially was published in 1930, and went through a number of printings. As a result of his extremism, clarity, and prominence, Frank drew substantial response from both fellow realists and ardent critics of legal realism.

In Law and the Modern Mind, Frank described "the basic legal myth"the myth of certainty-and explained its causes. He did not, however, prescribe a solution for it. Frank proclaimed that " $[t]$ he law always has been, is now, and will ever continue to be, largely vague and variable."22 And yet, according to Frank, the necessity of uncertainty in the law-even the existence of it-is denied. Why? To answer this question, Frank turned to psychiatry, in particular, to the child psychiatry of Jean Piaget. ${ }^{23}$ Frank attributed the need for, and belief in, certainty in the law to a child-like need for such certainty. ${ }^{24}$

Frank's account of child development was relevant to the myth of legal certainty because, inevitably, according to Frank, the law "becomes a par-

21 See Neil Duxbury, "Jerome Frank and the Legacy of Legal Realism," Journal of Law and Society (UK) 18 (1991), 176-177 (brief biographical sketch).

22 Jerome Frank, Law and the Modern Mind (New York: Brentano's, 1930), 6.

23 Jean Piaget was a Swiss psychologist who worked with Alfred Binet in testing the intelligence of children and wrote a number of books on childhood development. Frank acknowledged that, in Law and the Modern Mind, he "relied chiefly upon Piaget, an eclectic psychologist, who has done an immense amount of first-hand work with children.” Ibid., 326 note 1 (notes to Part One, Chapter II); see also ibid., 69n.* (citing three articles by Piaget).

24 See ibid., 13-16. To be fair, Frank asserted that he was providing only a "partial explanation" of the phenomenon he described, and included an appendix offering fourteen other "possible additional explanations of the basic legal myth." Ibid., xiii, 13, 263 (Appendix I). On the other hand, Frank's writing style was both provocative and repetitive, so it was easy for the reader to form the impression that the "partial explanation" was dominant, if not exclusive. See Robert Glennon, The Iconoclast as Reformer: Jerome Frank's Impact on American Law (Ithaca, NY: Cornell University Press, 1985), 48. 
tial substitute for the Father-as-Infallible-Judge." ${ }^{25}$ Caught between the uncertainty attendant to the practice of law-with its "changing realities," which require "recognition of novel circumstances, tentativeness, and adaptation" - and the desire to "achieve certainty, rigidity, security, uniformity" (the result of "unconscious longing for the re-creation of a child's world stimulated in all men ... by the very nature of law"), the lawyer essentially becomes a "professional rationalizer[ ]." 26 Frank, needless to say, objected to this state of affairs. In response, he urged the legal profession, basically, to grow up and embrace uncertainty, rather than attempt to avoid it or conceal it. ${ }^{27}$

Frank also focused his analysis on the understanding of rules and judicial decisions in the legal system. Frank chose Joseph Henry Beale, an accomplished Harvard Law School professor (and former student of Dean Langdell), to personify the conventional formalist view of what constitutes law. ${ }^{28}$ According to Frank, Beale defined law as "(1) [s]tatutes, (2) rules and (3) 'the general body of principles accepted as the fundamental principles of jurisprudence." ${ }^{29}$ Moreover, for Beale,

[t]his third element is "the one most important feature of law: that is ... a body of scientific principle. ... Law, therefore, is made in part by the legislature; in part it rests upon precedent; and in great part it consists in a homogeneous, scientific, and all-embracing body of principle [which is] ... "truly law" even "though no court has lent its sanction to many of [its] principles." 30

Frank railed against this view. The law as portrayed by Beale bore no resemblance to the law experienced by practicing lawyers. "Particular judgments of particular controversies are only vaguely predictable," observed Frank. ${ }^{31}$ Furthermore, he noted that "[d]ecisions in the courts of any given

25 Frank, Law and the Modern Mind, at 18; see also ibid., 20 ("Hence the basic legal myth that law is, or can be made, unwavering, fixed and settled.”).

26 Ibid., 30-31.

27 Ibid., 17-18 (discussing the career of William James, who made a "sudden shift from panic fear of insecurity to a deep enthusiastic bliss in the absence of security [which] marked for James the advent of emotional adulthood").

28 Ibid., 48 (Beale is "one of America's most influential legal writers from whom, at Harvard Law School, many of the leading lawyers of this country have received valued instruction. Beale's opinion, which is representative of the conventional doctrine, commands attention.”).

29 Ibid., 51.

30 Ibid., 51-52.

31 Ibid., 53. 
state ... vary." ${ }^{32}$ Borrowing from Holmes, Frank offered his own definition of the law "from the point of view of the average man," which he described as "a decision of a court with respect to [any particular set of] facts so far as that decision affects that particular person." 33 Thus far, Frank's critique was familiar, even, in its own way, conventional. Holmes, after all, already had observed that "a legal duty so called is nothing but a prediction that if a man does or omits certain things he will be made to suffer in this or that way by judgment of the court." 34

Frank extended this criticism, however, drawing upon the lessons he had learned from the emerging discipline of psychiatry. Focusing on the judge, Frank challenged the conventional view that "the judge begins with some rule or principle of law as his premise, applies this premise to the facts, and thus arrives at his decision." 35 Nonsense, insisted Frank. Instead, he argued that "[j]udicial judgments, like other judgments, doubtless, in most cases, are worked out backward from conclusions tentatively formulated." 36 Frank elaborated upon his challenge to the conventional view of judicial decisionmaking. He quoted favorably the description of Judge Joseph C. Hutcheson, Jr. that judging consisted of arriving at a "hunch," and then providing the "ratiocination" for the decision in the written opinion. ${ }^{37}$ Frank recognized the consequences of his argument: "Whatever produces the judge's hunches makes the law." 38 Although he acknowledged that the "rules and principles of law" were part of the stimuli that produced the judge's hunches, Frank nevertheless insisted that there were many "complicated" and "hidden" factors that influenced the individual judge. ${ }^{39}$

Frank did not confine his critique to the vagaries of the judge's personality. In addition to the fact that judges made decisions based upon hunches, Frank argued, the judicial fact-finding process was full of opportunity for error. ${ }^{40}$ Even honest witnesses made mistakes when they testified, and the risk for error increased due to the possibility that the judge or jury did

32 Ibid.

33 Ibid., 46.

34 Holmes, "The Path of the Law," 458.

35 Frank, Law and the Modern Mind, 101.

36 Ibid.

37 Ibid., 103-104.

38 Ibid., 104; see also ibid., 133 (noting that "the personality of the judge is the pivotal factor").

39 Ibid., 104-106.

40 Ibid., 110-111. Frank elaborated: If [the judge's] final decision is based upon a hunch and that hunch is a function of the "facts," then of course what [the 
not correctly understand the testimony or became distracted while listening to the witness. ${ }^{41}$

One should not exaggerate the novelty of Frank's insights-even Frank acknowledged that much of his book merely debunked myths about the legal system told by lawyers and judges for the general audience. In part, it was the vehemence of his assault on the legal system that made his claims bold and provocative, especially for the era in which they were written. Frank effectively held up a mirror to the legal system, and reflected back something akin to the abyss. At the time, it was difficult to conceive of a more direct assault on the inductive logic of formalism. The operating legal principles, said to be discoverable in the law books and reported cases in the library, did not resolve cases, and did not provide definitive guidance on the outcome of a legal dispute. Frank did not shy away from the implications of his argument: If the administration of justice was idiosyncratic, it could not be said that litigants received equal treatment in the legal system. ${ }^{42}$

Frank did not provide a programmatic solution to improve the judicial system he described in Law and the Modern Mind. He agreed with reformers that psychology could provide further insights into how individual judges decided cases, but acknowledged that such efforts depended upon the willingness of the "judges to engage in searching self-analysis." ${ }^{43}$ However, he did not expect most judges to be willing to engage in such selfanalysis. ${ }^{44}$ Still, the best lawyers and judges can do, according to Frank, is grow up. This meant embracing change, accepting uncertainty, and liberating civilization from "father-governance." 45

Law and the Modern Mind received a broad but divided reception. Although critics agreed that Frank's book was "provocative," 46 not every reviewer employed that description with favor. A number of prominent pro-

judge], as a fallible witness of what went on in his courtroom, ... believes to be the "facts," will often be of controlling importance. So that the judge's innumerable unique traits, dispositions and habits often get in their work in shaping his decisions not only in his determination of what he thinks fair or just with reference to a given set of facts, but in the very processes by which he becomes convinced what those facts are. Ibid.

41 Ibid., 106-111.

42 See ibid., 111-112.

43 Ibid., 113-114.

44 See ibid., 116-117.

45 See ibid., 243-252.

46 See Felix S. Cohen, “Among Recent Books,” ABA Journal 17 (1931), 111 (book review) (located in Jerome Frank Papers, Box 128 Folder 3) (describing Law and 
fessors and writers praised Law and the Modern Mind. ${ }^{47}$ More revealing than the positive reviews, however, were the critical ones. Initially, Law and the Modern Mind was challenged for its method, or its science. These reviews questioned whether Frank had accurately described the operation of the legal system, whether he had properly weighed the value of certainty in a legal system, and whether he reasonably relied upon psychiatry as an explanatory extra-legal discipline.

For example, Mortimer Adler, a University of Chicago philosopher who embraced foundational principles, ${ }^{48}$ sounded a sharp note in his assessment of Law and the Modern Mind in the Columbia Law Review in 1931. Frank's book offended Adler from start to finish. According to Adler, Law and the Modern Mind was a lawyer's brief rather than a philosopher's discussion, demonstrating flaws in logic and argument, and erring even in its understanding of psychiatry. ${ }^{49}$ Adler dismissed Frank as "an extreme nominalist" for whom "nothing exists except particulars, and words are merely their names." 50 Adler's assault, though sweeping, centered on the shortcomings of Law and the Modern Mind as a work of philosophy.

What is worth noting about the reception of Law and the Modern Mind immediately after its publication is that the debate over the book revolved

the Modern Mind as "the most provocative stimulus to thinking on fundamental legal problems ... in the Anglo-American literature of jurisprudence since Dean Pound's Spirit of the Common Law"); see also Charles E. Clark, "Jerome N. Frank," Yale Law Journal 66 (1957), 817 (stating that "Law and the Modern Mind fell like a bomb on the legal world").

47 See Karl Llewellyn, "Legal Illusion," Columbia Law Review 31 (1931), 82 ("This book excites. ... It is well-nigh unique in attempting exploration of emotional drives and genetic psychology for their contribution to our understanding of the ways of law."); Walter Wheeler Cook, "Legal Logic," Columbia Law Review 31 (1931), 108 (defending Law and the Modern Mind against attack by Mortimer Adler); see also Thurman W. Arnold, "Law and Men," Saturday Review of Literature (1931), 644 (located in Jerome Frank Papers, Box 128 Folder 3). Earlier in 1931, Arnold wrote a letter to Frank in which he observed that Mortimer Adlerin his review in the Columbia Law Review - "appears to throw big words at you like a comedian throws custard pies." Letter from Thurman Arnold to Jerome Frank (Jan. 15, 1931) (located in Jerome Frank Papers, Box 4 Folder 108). Arnold returned to this image in his article for the Saturday Review of Literature. See also Max Radin, "Giving Away the Legal Show," New York Harald Tribune, Dec. 21, 1930, Books 5 (located in Jerome Frank Papers, Box 128 Folder 3).

48 See Purcell, The Crisis of Democratic Theory, 3 (noting that Adler believed "that human reason could discover certain immutable metaphysical principles that explained the true nature of reality").

49 See Mortimer J. Adler, "Legal Certainty,” Columbia Law Review 31 (1931), 91.

50 Ibid., 98. 
around the soundness of its science. This inquiry did not focus on the political implications associated with an arbitrary judicial system. Frank's book did not, in 1931, pose a threat outside the academy. As the decade progressed, this would change, and Frank and the legal realists would come under fire for the political values associated with their jurisprudence. On the eve of and during World War II, those critics could be sharp: Legal realism, they charged, permitted-indeed, was synonymous with-fascism.

Indeed, by the end of the 1930s, virtually no academic discussion could occur without reference to the political developments in Europe and elsewhere. An increasingly popular attack on legal realism was that it permitted fascism. This development is reflected, in part, in the Julius Rosenthal Lectures Professor Fuller gave at Northwestern University in $1940 .{ }^{51}$

The development of Fuller's views on legal realism illustrate the turn of the jurisprudential tide against legal realism. Initially, Fuller appreciated the anti-formalist insights offered by the legal realists, though he insisted upon a more purposive and value-laden understanding of the law and the legal system through which it developed..$^{52}$ As the 1930s progressed, however, Fuller joined the chorus of natural law scholars criticizing legal realism. In 1940, Fuller's book, The Law in Quest of Itself (which collected his lectures at Northwestern), sharply and specifically condemned the legal philosophies of positivism (and its related successor, legal realism) for contributing to the emergence of fascist governments in Germany and Spain.

In his second speech, Fuller addressed legal realism. He viewed legal realism as a modern form of positivism-one that sought "to anchor itself in some datum of nature, which considers that the law's quest of itself can end successfully only if it terminates in some tangible external reality." ${ }^{53}$ In their studies of judicial behavior, according to Fuller, the legal realists modified positivism, focusing on what judges do rather than on what they

51 Fuller's opportunity to give the Rosenthal lectures came shortly after he arrived at Harvard Law School in 1939 for a stint as a vising professor from Duke Law School. Robert S. Summers, Lon L. Fuller (Stanford, CA: Stanford University Press, 1984), 5-6. Fuller subsequently received a permanent appointment at Harvard, retired in 1972, and died in 1978. Ibid., 7, 13.

52 See Lon Fuller, "American Legal Realism," University of Pennsylvania Law Review 82 (1934), 429.

53 Fuller, The Law in Quest of Itself, 47; see also ibid., 55 (“[T]he psychology involved in the realist view is largely indigenous to the soil of legal positivism.”). Fuller cited Frank's Law and the Modern Mind as one of "the most important expositions of the realist conception of law." Ibid., 52 note 11. 
say. ${ }^{54}$ Indeed, Fuller argued, the legal realists insisted upon "a sharp line between the rules that judges act on and those they talk about ... a field [of] pure judicial behavior" that corresponded to Austin's sovereign. ${ }^{55}$

In his final lecture, Fuller connected his critique of positivism to current political developments. "We live in a period when major readjustments in our economic and social order have become necessary," he wrote. ${ }^{56}$

It would seem that the present is a time when our social structure requires to be held together by a cement firmer than that supplied by the abstract principle of respect for law as such. If Renan was right in assuming that men have the capacity for developing the illusions necessary for their survival, we ought to be seeing a revival of natural law. ${ }^{57}$

Under the philosophy of positivism, Fuller continued, "[s]ince power rests ultimately on the acquiescence of the governed, the most logical principle of government is that of majority rule, since this offers the broadest base for the order set up." 58 Fuller was dismayed by this view of democracy: It did not provide for justice, and did not come "closer to the inner essence of things than the will of any particular individual." 59 Moreover, he argued that this "purely negative ... conception of democracy"-based upon only the exercise of power by the majority — has "played an important part ... in bringing Germany and Spain to the disasters which engulfed those countries." 60

With respect to Germany, Fuller elaborated:

It was only this conception [of democracy] which could mislead men into believing that the power relations inside a society could be radically displaced by the mere will of a numerical majority, or that a social and economic revolution could be accomplished through a democratic control unsustained by any common faith or program. It was this conception which lulled men into the dangerous dream that a kind of political euthanasia of vested interests would be possible. In the rude awakening which followed this dream there was demonstrated, at least in Germany, not only the futility of the dream itself, but

54 See ibid., 52.

55 Ibid., 59.

56 Ibid., 115.

57 Ibid., 116.

58 Ibid.

59 Ibid., 121.

60 Ibid., 122. 
the inability of repressive violence to fill the void left by a defaulting principle of majority rule, for the purported counter-revolution of Nazism has in many cases only increased the tempo and violence of the disintegrative forces from which it claimed to be rescuing Germany. ${ }^{61}$

As world events brought the United States closer to, and then into, World War II, critics of legal realism compared the realists to the emerging fascist governments in Europe, in particular the Nazi regime in Germany. By divorcing law from morality, insisting upon retaining an air of scientific detachment, and denying the significance of legal rules, the realists appeared to embrace the notion that power-and only power-was relevant to and necessary for governance. Compared to claims made by other natural law scholars in the early 1940s, Fuller's critique seemed positively mild. In 1942, for example, Father Francis E. Lucey of Georgetown wrote: "Realism is being tried out today in Germany and Russia." ${ }^{62} \mathrm{He}$ argued, "The Jurisprudence of these countries is the 'Is' Instrumentalism or Pragmatism of the Realist. What works is good. They exclude principles and morals and God from the picture of law, national and international." ${ }^{33}$ Lucey continued: "For Holmes and the realist[, man] is a sort of superior animal. ... If man is only an animal, Realism is correct, Holmes was correct, Hitler is correct." 64

\section{World War II, the Nuremberg Trials, the Decline of Legal Realism, and the Revival of Natural Law Theory}

After World War II, attention turned to development of a new political order. Immediately after the war, some in the United States desired-and even were optimistic about the prospect of-a new world order governed by international law. The idea of human rights, for example, reflected this

61 Ibid.

62 Francis E. Lucey, "Natural Law and American Legal Realism: Their Respective Contributions to a Theory of Law in a Democratic Society," Georgetown Law Journal 30 (1942), 523.

63 Ibid.; see also Purcell, The Crisis of Democratic Theory: 164-172 (describing the attack by Catholic natural law scholars on legal realism).

64 Lucey, "Natural Law and American Legal Realism," 531; see also Purcell, The Crisis of Democratic Theory, 157-158 (quoting Robert Hutchins, former Yale Law School Dean, as saying, "[t] here is little to choose between the doctrine I learned in an American law school ... and that which Hitler proclaims”). 
sentiment. ${ }^{65}$ A working definition of human rights, from the perspective of the United States in 1945, was the idea that individuals in a foreign state have "universal, objective human rights ... regardless of the content of [that foreign state's] positive law." ${ }^{\prime 6}$ This idea of human rights reflected natural law principles.

However, the vindication of human rights potentially conflicted with another fundamental legal principle: the due process protection against retroactive laws. Although there was (and is) not an absolute protection against retroactive lawmaking, the principle of due process protects individuals against liability —and even more strongly, against criminal punishment-for conduct that was neither illegal nor prohibited when it occurred. This concern about retroactive lawmaking reflected positivist principles. In the post-war period, the protection against retroactive lawmaking was subordinated to the human rights principle that some rights exist independent of the state's laws, and that some conduct is wrong-and may be judged as such—even if that conduct is not prohibited by law. ${ }^{67}$

The clash between the natural law notion of human rights and the positivist concern about retroactive lawmaking is reflected in the writings of both Frank and Fuller after World War II. Fuller discussed it in a debate about the validity of Nazi laws after the war, while Frank addressed this conflict in the context of the Nuremberg trials. ${ }^{68}$ In an article published in Collier's in 1945, Frank defended the necessity of the trials for the sake of world peace. In this discussion, he specifically noted the "moral effect" of the trials, and enlisted this value in the cause of establishing a new world order. ${ }^{69}$ That natural law principles seemed to triumph is just one indication of their revival during this period.

65 See Primus, “A Brooding Omnipresence," 429-430.

66 Ibid., 430.

67 See ibid., 431.

68 Herbert Wechsler acknowledged the retroactivity charge but insisted that, in the context of law and politics of international relations, the defendants had received sufficient prior notice that they could be punished criminally for their conduct. See Herbert Wechsler, “The Issues of the Nuremberg Trial," Political Science Quarterly 62 (1947), 11, reprinted in Herbert Wechsler, Principles, Politics and Fundamental Law (Cambridge, MA: Harvard University Press, 1961), 153-155.

69 Jerome Frank, "War Crimes: Punishment for Today-Precedent for Tomorrow," Collier's, Oct. 13, 1945, 73. Frank elaborated: [T] he principal purpose of the trials is not the regeneration or the re-education of Germany. Far more important is the moral effect on other peoples ... With the dropping of the first atomic bomb on August 6, 1945, lasting world peace became the immediate concern of everybody on this planet, including the hard-headed practical realists. For the maintenance 
The Nuremberg trials were an extraordinary event, and important to United States's post-war foreign policy. It therefore is not entirely surprising that Frank would set aside his skepticism of judges and the judicial process in endorsing the efforts of Justice Jackson and the goals of the war crimes trials. Nevertheless, it is worth noting that his discussion of the Nuremberg trials did not even resonate with, much less mention, his usual criticisms of the trial process-the childish quest for certainty, the limits inherent in the judicial fact-finding process, the intuitive quality of judging. Frank's silence is even more notable given the novelty of the tribunal, as well as its task-to pass legal judgment on the conduct of individuals pertaining to international affairs and war.

The Collier's article is important also because it is one of the earliest indications of Frank's acknowledgment - if not embrace- of natural law principles. ${ }^{70}$ In his post-war books, Frank responded to criticism that his emphasis on "fact skepticism" indicated a lack of commitment to valuesby acknowledging basic natural law values and by emphasizing that his work aimed to improve fairness in the judicial system (and was intended to promote democratic government). ${ }^{71}$ To be sure, Frank did not abandon his earlier views and become a disciple of natural law. He continued to address the limits of the trial process and to insist that psychiatry remained crucial to understanding the individual decisions made by trial judges. Natural law was not, and could not be, "practically meaningful," because "[n]atural [1]aw aims at justice and at moderate certainty ... in the more or less abstract, generalized human formulations of what men may or may not lawfully do[, and] ... judicial justice must be justice ... in the concrete —in the courts' decisions of the numerous particular individual cases." ${ }^{\prime 2}$

of such peace a vigorous, organized world order is imperative. The Nuremberg trial signalizes the emergence of such a world order ... To the prisoners' dock are called men once mighty—among others, a Reich Minister Goering, a Foreign Minister Von Ribbentrop, a Labor Minister Ley, a Field Marshall Keitel. Their very presence dramatically affirms that a robust world morality is alive at this moment, that a world conscience is on its way to becoming an accepted world custom. Ibid.

70 See Duxbury, "Jerome Frank and the Legacy of Legal Realism," 194, 203 note 130 ("In the 1940s Frank 'found' natural law."). The Collier's article is the earliest writing by Frank cited in Duxbury's discussion of Frank and natural law. See ibid.

71 See ibid., 185-86, 194-96.

72 Jerome Frank, Law and the Modern Mind (6th ed. 1949), xviii. Frank elaborated on these points in his other book published in 1949, Courts on Trial: Myth and Reality in American Justice (Princeton, NJ: Princeton University Press, 1949), 346-374. 
Frank was more vehement about his concern for democracy in the postwar era. Even before the Cold War dashed hopes for a world order regulated by a regime of international law, there was anxiety in the United States about the fate of democracy in the post-war period. Some of this anxiety stemmed from the example of Nazi Germany, which revealed the nightmare possible through tyranny of the majority. Frank's post-war writings consistently noted and addressed this concern for democracy. In the sixth printing of Law and the Modern Mind, published in 1949, Frank emphasized that his efforts to demystify the trial court process were motivated by a desire to ensure fair trials, which were vital to democracy. ${ }^{73}$ It may be argued that Frank's concern for democracy, acknowledgment of natural law, and proposals for reforming the judicial system resulted from his own efforts to "grow up" since he wrote Law and the Modern Mind in 1930. Yet, it is also the case that these developments in Frank's jurisprudence reflected the revival of natural law in the United States-a shift that itself resulted from and reflected concerns about totalitarian governments, in particular Nazi Germany.

The issue of retroactivity, briefly taken up by Frank in his Collier's article, is at the heart of the debate between Professors Fuller and Hart. ${ }^{74}$ Fuller's 1958 debate with English philosopher H.L.A. Hart over positivism in the Harvard Law Review is perhaps the most famous jurisprudential exchange of the twentieth century. ${ }^{75}$ As I will discuss, the specter of Nazi Germany informed-even framed-the exchange. Central to the debate was a disagreement over judicial treatment of laws enacted and enforced while the Nazi government was in power. Although neither Fuller nor Hart specifically discussed the Nuremberg trials, the debate over retroactive invalidation of Nazi laws paralleled the retroactivity issue raised by the war crimes prosecutions.

73 See Frank, Law and the Modern Mind, supra note 73, xix.

74 See supra note 70 and accompanying text.

75 See H. L. A. Hart, "Positivism and the Separation of Law and Morals," Harvard Law Review 71 (1958), 593; and Lon L. Fuller, "Positivism and Fidelity to Law-A Reply to Professor Hart," Harald Law Review 71 (1958), 630. This debate has been described as "the most interesting and illuminating exchange of views on basic issues of legal theory to appear in English in [the twentieth] century." See Summers, Lon L. Fuller, 10. Many commentators have acknowledged both the quality as well as the significance of the exchange. See, e.g., Carl Landauer, "Deliberating Speed: Totalitarian Anxieties and Postwar Legal Thought," Yale Journal of Law \& the Humanities 12 (2000), 171, 217 (referring to Fuller's "famous 1958 exchange with H.L.A. Hart in the Harvard Law Review"). 
The specific question addressed in the exchange was the validity of laws that had been enacted by the Nazi government and had been invoked to perpetrate wrongful acts. In German legal proceedings after World War II, could litigants defend their actions on the grounds that they were authorized by Nazi laws? This question paralleled the retroactivity debate over the Nuremberg prosecution: In the post-war German cases, the courts relied upon natural law principles to invalidate Nazi laws, and thereby denied litigants the protection claimed by positive Nazi law. In the Nuremberg trials, the prosecution effectively relied upon natural law principles to retroactively criminalize conduct that previously had not been illegal under international law. In both cases, natural law principles were cited to justify prosecution and punishment of individuals who committed legally permissible but morally reprehensible acts while the Nazi government was in power. The specter of Nazi Germany framed the debate: Hart vigorously denied the connection between positivism and Nazism. ${ }^{76}$ Fuller-citing the history of positivism in German jurisprudence-argued to the contrary. ${ }^{77}$ Fuller asserted that "if German jurisprudence had concerned itself more with the inner morality of law, it would not have been necessary" to confront the legal question of whether to invalidate "the more outrageous Nazi statutes."78

In presenting his general case for positivism, Hart argued for the separation of law and morals through an account of the utilitarian philosophy of Bentham and Austin. He connected positivism with the political reforms they championed. Bentham and Austin "were not," Hart wrote, "dry analysts fiddling with verbal distinctions while cities burned, but were the vanguard of a movement which laboured with passionate intensity and much success to bring about a better society and better laws." 79 When Hart turned to criticism of positivism based on the example of Nazi Germany, he sought to downplay the argument by describing it as "less an intellectual argument ... than a passionate appeal supported not by detailed reason-

76 See Hart, "Positivism and the Separation of Law and Morals," 617-618. The literature on this debate is extensive, and continues today. See Primus, "A Brooding Omnipresence," 432-433 and note 61.

77 See Fuller, "Positivism and Fidelity to Law," 657-661.

78 Ibid., 659-660.

79 Hart, "Positivism and the Separation of Law and Morals," 596. 
ing but by reminders of a terrible experience." ${ }^{80}$ Nevertheless, Hart seemed to be on the defensive as he began his presentation. ${ }^{81}$

Hart then addressed the retroactivity issue. After World War II, the German courts had to decide cases in which "local war criminals, spies, and informers under the Nazi regime were punished." 82 The cases presented a dilemma: The persons punished after the war had been prosecuted for actions authorized by laws enacted during the Nazi regime; now, however, those laws did not provide a defense because they were immoral and therefore were not valid. For example, as Hart summarized:

In 1944 a woman, wishing to be rid of her husband, denounced him to the authorities for insulting remarks he had made about Hitler while home on leave from the German army. The wife was under no legal duty to report his acts, though what he had said was apparently in violation of statutes making it illegal to make statements detrimental to the government of the Third Reich or to impair by any means the military defense of the German people. The husband was arrested and ... was sent to the front. In 1949 the wife was prosecuted [pursuant to an 1871 law that had been in force since its enactment] in a West German court for an offense which we would describe as illegally depriving a person of his freedom. ... The wife pleaded that her husband's imprisonment was pursuant to the Nazi statutes and hence that she had committed no crime. ${ }^{83}$

Ultimately, the wife was found guilty of depriving her husband of his freedom. The German appellate court invalidated the Nazi law cited by the wife as "contrary to the sound conscience and sense of justice of all decent human beings." 84

Although, as Hart noted, "[m]any of us might applaud the objective" of the court's decision, Hart was disturbed by the result, because the court had found that a validly enacted law did not, in fact, have the force of

80 Ibid., 615.

81 See ibid., 616. Hart acknowledged that among the post-war critics of positivism were "German thinkers who lived through the Nazi regime and reflected upon its evil manifestations in the legal system," citing Gustav Radbruch, who had "shared the 'postivist' doctrine until the Nazi tyranny" but essentially recanted those views after the war. Ibid.

82 Ibid., 618.

83 Ibid., 618-619.

84 Ibid., 619. 
law. ${ }^{85}$ The better solution, Hart argued, would have been for the legislature to pass "a frankly retrospective law" that at least would have acknowledged that "in punishing the woman a choice had to be made between two evils, that of leaving her unpunished and that of sacrificing a very precious principle of morality endorsed by most legal systems." 86 Positivism demanded candor, and Hart believed it was necessary to expressly resolve the moral dilemma between delivering justice in the woman's case and observing the duty to obey the law by passing a new law to supersede the prior Nazi laws.

Fuller did not believe that the case presented such a dilemma. In a more detailed response, he analyzed the Nazi statutes relied upon by the wife, and argued that they did not provide a valid defense because they did not have the quality of law. Fuller argued that one of the statutes, enacted in 1934, had been applied in an overbroad manner, while the other statute, enacted in 1938, was a "legislative monstrosity" that permitted "uncontrolled administrative discretion." 87 Whether a court or an individual was required to follow such laws (simply because of their status as laws) or to instead "do what we think is right and decent" 88 did not create a dilemma for Fuller. "I do not think it is unfair to the positivistic philosophy to say that it never gives any coherent meaning to the moral obligation of fidelity to law," Fuller concluded. ${ }^{89}$ Although Fuller also endorsed the enactment of a new statute to invalidate the earlier laws, he justified that choice on entirely different grounds: The adoption of a new law would "symboliz[e] a sharp break with the past," and help usher in a new, lawful regime. ${ }^{90}$ Although Fuller did not discuss the Nuremberg trials, his remarks endorsed the natural law justifications for the Nuremberg trials.

Finally, it is worth noting an indication of the rise of natural law and corresponding decline of positivism was Hart's concession that, under certain extreme circumstances, a law may be so immoral as to not require obedience. ${ }^{91}$ Hart's admission that the content of a law could justify disobedience tainted the purity of his case for positivism-a damaging conces-

85 Ibid.

86 Ibid.

87 Fuller, "Positivism and Fidelity to Law," 652-654.

88 Ibid., 656.

89 Ibid.

90 Ibid., 661.

91 Hart, "Positivism and the Separation of Law and Morals," 616-617; see also Landauer, "Deliberating Speed," 217-218 (discussing Hart's concession). 
sion when defending a legal philosophy that championed adherence to the law.

\section{The Nuremberg Trials and the Development of Legal Process Theory}

Natural law theory sought to prevent the reoccurrence of a totalitarian regime such as Nazi Germany by expressly incorporating moral considerations into the evaluation of positive laws. Legal process represented an alternative response to the concerns about totalitarianism (including facism, as exemplified by Nazi Germany). As Professor William Wiecek has explained, legal process proponents viewed "the legal system as ... both a collection of substantive rules and as 'a structure of decision-making processes." "92 They believed that substantive rules "rest[ed] ultimately on conflicting rules best reconciled by the political branches, not the courts," while "[ $t]$ he processes of law [were] the lawyer's domain, where legal expertise is both most needed and most readily justified." 93 Instead of approving natural law reasoning by courts - that is, encouraging the consideration of morality in the act of judging-process jurisprudence cabined judges. By confining policy disputes to political branches and confining judges to a particular institutional role, process jurisprudence aimed to promote democracy. In what follows, I will discuss the influence of the Nuremberg trials on legal process theory through the example of Herbert Wechsler, a leading proponent of the theory, focusing on his famous Neutral Principles article. ${ }^{94}$

Wechsler enjoyed an extraordinarily distinguished career as both a law professor and practicing attorney. He is the only author discussed in this Article who was directly involved in the Nuremberg trials. During World War II, Wechsler served as Assistant Attorney General in charge of the War Division. At the end of the war, Wechsler helped shape the nature and scope of the war crimes prosecution efforts, and subsequently served as an

92 William M. Wiecek, "American Jurisprudence after the War: "Reason Called Law,” Tulsa Law Review 37 (2002), 857, 868.

93 Ibid., 868. See also Donald A. Dripps, "Justice Harlan on Criminal Procedure: Two Cheers for the Legal Process School," Ohio State Journal of Criminal Law 3 (2005), 126 ("Policy choices, on the legal process account, ought to be made by institutions best equipped for the kind of questions at hand.").

94 See Herbert Wechsler, "Toward Neutral Principles of Constitutional Law," Harvard Law Review 73 (1959), 1. 
advisor to the judicial tribunal at Nuremberg. ${ }^{95}$ After his service in Nuremberg, Wechsler wrote an article defending the legitimacy of the prosecution and the tribunal. ${ }^{96}$

Wechsler's experience in Nuremberg influenced his writings on legal philosophy, including his famous 1958 Oliver Wendell Holmes lecture at Harvard. That lecture became the basis for his most well-known article, Toward Neutral Principles of Constitutional Law. ${ }^{97}$ That article generated great interest-and still merits scholarly attention-because of its criticism of the Supreme Court's reasoning in Brown v. Board of Education ${ }^{98}$ (though not its result, which Wechsler supported). ${ }^{99}$ As Wechsler has stated, there is a connection between his service at Nuremberg and his ideas set out in Neutral Principles.

There are at least three aspects of the Nuremberg trials that are relevant to the legal process school, in particular, Wechsler's views. First, process theorists distinguished law from politics. Wechsler, for example, sounded this note early in his Neutral Principles article. ${ }^{100} \mathrm{He}$ did not deny that principles have a role in politics, but the role of principle in the political arena was limited to that of a "manipulative tool." With courts, "something else is called for," and Wechsler insisted "that the main constituent of the judicial process is precisely that it must be genuinely principled, resting with respect to every step that is involved in reaching judgment on analysis and

95 See Norman Silber and Geoffrey Miller, "Toward 'Neutral Principles' in the Law: Selections from the Oral History of Herbert Wechsler," Columbia Law Review 93 (1993), 854, 856-857.

96 See Herbert Wechsler, "The Issues of the Nuremberg Trial," Political Science Quarterly 62 (1947), reprinted in Wechsler, Principles, Politics and Fundamental Law (1961), 138-157.

97 See Wechsler, "Toward Neutral Principles". In the constitutional law literature, the "Neutral Principles" article has been extensively discussed and widely cited. See, e.g., Cass R. Sunstein, "Neutrality in Constitutional Law (with Special Reference to Pornography, Abortion, and Surrogacy)," Columbia Law Review (1992), 5 (commending the "Neutral Principles" article as " $[t]$ he most celebrated essay in all of constitutional law"); Fred R. Shapiro, "The Most-Cited Law Review Articles," California Law Review 73 (1985), 1540, 1549 (tabulating Neutral Principles as the second most heavily cited law review article).

98347 U.S. 483 (1954).

99 See infra notes $111,114-115$ and accompanying text.

100 See Wechsler, "Toward Neutral Principles," 12. Wechsler elaborated: "The man who simply lets his judgment turn on the immediate result may not, however, realize that his position implies that the courts are free to function as a naked power organ, that it is an empty affirmation to regard them, as ambivalently he so often does, as courts of law." Ibid. 
reasons quite transcending the immediate result that is achieved."101 Wechlser elaborated on this point, articulating a central principle of the legal process school:

[M] ust [courts] not decide on grounds of adequate neutrality and generality, tested not only by the instant application but by others that the principles imply? Is it not the very essence of judicial method to insist upon attending to such other cases, preferably those involving an opposing interest, in evaluating any principle avowed? ${ }^{302}$

Wechsler previously had addressed the distinction between law and politics in his article defending the legitimacy of the Nuremberg tribunal's work. ${ }^{103}$ The strongest criticism of the Nuremberg trials was that "victor's justice" was administered at the trials, and that the trials were merely political affairs in which justice was neither sought nor administered. Wechsler acknowledged this criticism but nevertheless insisted that the legality of the proceedings-in which a formal indictment was issued, counsel was provided, and trial procedures were followed-ensured a more fair process and outcome than the prevailing political solution at the time, which was summary execution.

Second, although Wechsler did not specifically mention this point in his article defending the tribunal, it is the case that the judges at Nuremberg were required to articulate the reasons for their judgment. In an interview at the end of his career, Wechsler stated that "the principal function of Nuremberg and supplementary trials was not to administer punishment, but to influence its withholding, its postponement, while passions cooled, and to give reason a chance to be operative in determining who deserved to be punished." 104 The tribunal's reasoned explanation was not only superior to the politically popular alternative of summary execution, it also required a more reasoned decision than, for example, a jury verdict, which is made after secret deliberations and does not include an explanation. Wechsler adverted to this point in Neutral Principles when he noted that "[a]n attack upon a judgment involves an assertion that a court should have decided otherwise than as it did. Is it not clear that the validity of an

101 Ibid., 15.

102 Ibid.

103 See Wechsler, "The Issues of the Nuremberg Trial," 153.

104 Silber \& Miller, supra note 96, at 913 (emphasis added). 
assertion of this kind depends upon assigning reasons that should have prevailed with the tribunal; and that any other reasons are irrelevant?" 105

Third, and finally, Wechsler insisted that the Nuremberg tribunal acted on-and attempted to articulate- a sufficiently neutral principle: the notion that the judging countries would agree and be subject to the same principles applied in their judgment of the Nazi defendants. ${ }^{106}$ In the interview noted above, Wechsler had the following exchange with the interviewers:

Was the neutral principles article in some ways the crystallization of your Nuremberg experience?

I wouldn't put it that way. On the other hand, what I wrote about Nuremberg-particularly my emphasis on the importance, in that undertaking, that we judge the enemy only by standards that we would apply to ourselves, be willing to apply to ourselves, and feel obliged to apply to ourselves-does represent an articulation of my belief in neutral principles back then. My whole effort in the Nuremberg thing, in which I think I was on the whole quite successful in strengthening the natural instinct of Judge Biddle to perform in this way, was to persuade him that in reaching judgment at Nuremberg, only standards that we felt confident we would be ready to apply to ourselves should prevail. Over and over again in my memoranda, this point would be made. ${ }^{107}$

\section{The Nuremberg Trials and Brown v. Board of Education}

In this Article, I have discussed the influence of the Nuremberg trials and the example of Nazi Germany only in the American legal academy, in relation to the decline of legal realism and the revival of natural law and emergence of legal process after World War II. Nuremberg and Nazi Germany also influenced the development of constitutional law during the post-war period as well. In taking this brief detour, I only want to note that with

105 Wechsler, "Toward Neutral Principles," 11; see also ibid., 19 (explaining that "[a] principled decision ... is one that rests on reasons with respect to all the issues in the case, reasons that in their generality and their neutrality transcend any immediate result that is involved," and that "[w]hen no sufficient reasons of this kind can be assigned for overturning value choices of the other branches of the Government or of a state, those choices must, of course, survive").

106 See Wechsler, "The Issues of the Nuremberg Trial," 156-157.

107 Silber and Miller, "Toward 'Neutral Principles'," 930. 
respect to Nuremberg and the example of Nazi Germany, the case law generally runs the same way as the academic discussion-in the direction of natural law foundationalism.

Richard Primus has attributed the Supreme Court's reversal of its position in the flag salute cases and the Japanese internment cases, and its decision in the Steel Seizure Case, to, in part, the concerns raised by the example of Nazi Germany. ${ }^{108}$ Perhaps the most compelling illustration of the influence of Nazi Germany on the Supreme Court is-as Primus and others have suggested-Brown v. Board of Education, ${ }^{109}$ in which the Court held that separate-but-equal public schools for African-American children violated the Constitution's Equal Protection Clause. ${ }^{110}$ The Nuremberg trials contributed to the growing sentiment against segregation that enabled the Court's decision in Brown. ${ }^{111}$

Brown represents the culmination of the developments previously discussed in this Article in a number of ways. First, a foundational principle in the post-war world was racial nondiscrimination. ${ }^{112}$ Brown enshrined that principle in the law of the United States, in a morality-based decision. ${ }^{113}$ Second, Brown launched an era of greater judicial activism. This development was necessary to guarantee the protection of foundational principles, and reflected the post-war rejection of the legal realist's demystified depiction of the judge.

108 See Primus, “A Brooding Omnipresence," 437-443.

109347 U.S. 483 (1954).

110 See Primus, “A Brooding Omnipresence," 437, 447-449; see also Constance Baker Motley, "The Historical Setting of Brown and Its Impact on the Supreme Court's Decision,” Fordham Law Review 9, 61 (1992), 12 (explaining that racial segregation during World War II embarrassed the United States, and helped bring about the Supreme Court's decision in Brown).

111 See William E. Nelson, "Brown v. Board of Education and the Jurisprudence of Legal Realism," Saint Louis University Law Journal 48 (2004), 795, 812. "The Nuremberg trials, as well as massive press coverage of Nazi atrocities, served to inform the wider American public of the horrors of the Third Reich's Final Solution. All of this would help make the kind of easy yet deep racial prejudice common earlier in the century far less respectable after the Second World War." Ibid. (quoting Robert J. Cottrol, Raymond T. Diamond, and Leland \& and Ware, "Brown v. Board of Education," Caste, Culture, and the Constitution 97 [2003]).

112 See Primus, “A Brooding Omnipresence," 447-448.

113 See Richard Fallon, "Legitimacy and the Constitution," Harvard Law Review 118 (2005), 1787, 1836 (arguing that Chief Justice Warren's "reasoning” in Brown "can easily be understood as advancing a substantially moral justification"). 
Third, Brown demonstrated that although legal realism no longer remained viable as an autonomous legal philosophy, it continued to influence American case law and jurisprudence. ${ }^{114}$ This influence is shown in Brown in the Court's reliance upon extra-legal materials to support its decision-specifically, the social science studies involving dolls cited by the Court, which demonstrated that racial segregation "generates a feeling of inferiority." 115

Finally, Brown figures prominently into Wechsler's Neutral Principles article-not because of the correctness of its result, but instead because of the shortcomings in its reasoning. Wechsler addressed Brown in connection with his consideration of the Court's contemporary equal protection cases. ${ }^{116}$ Before evaluating the decisions from a "neutral principles" perspective, Wechsler stated that the Court's equal protection decisionswhich invalidated "white primary" elections, ${ }^{117}$ judicial enforcement of restrictive covenants, ${ }^{118}$ and segregated schools ${ }^{119}$ - "have the best chance of making an enduring contribution to the quality of our society of any that I know in recent years." 120

Nevertheless, Wechsler found the reasoning in the Court's decisions inadequate. Specifically, Wechsler explained: "[T]he separate-but-equal for-

114 See Robert J. Cottrol, “Justice Advanced: Some Comments on William Nelson's Brown v. Board of Education and the Jurisprudence of Legal Realism," Saint Louis University Law Journal 48 (2004), 839, 850 ("Brown made a difference precisely because the advocates urging desegregation and the Court that accepted their arguments tapped into the changed mood and needs of the nation. In doing so they proved that they had learned the realist lesson well.”); see also John Valery White, "Brown v. Board of Education and the Origins of the Activist Insecurity in Civil Rights Law,” Ohio Northern University Law Review 28 (2002), 303, 306 (arguing that Brown "would give form and substance to realism, even as realism was being transformed").

115 Brown v. Board of Education, 347 U.S. 494 and note11. The Court stated: "Whatever may have been the extent of psychological knowledge at the time of Plessy $v$. Ferguson, this finding is amply supported by modern authority." Ibid. (citing psychology studies).

116 See Wechsler, "Toward Neutral Principles," 26.

117 Smith v. Allwright, 321 U.S. 649 (1944) (discussed in Wechsler, "Toward Neutral Principles,"26-27).

118 See, e.g., Shelley v. Kraemer, 334 U.S. 1 (1948) (discussed in Wechsler, "Toward Neutral Principles," at 26-27).

119 Brown v. Board of Education, 347 U.S. 649 (discussed in Wechsler, "Toward Neutral Principles," 31-34). Wechsler added that "for one of my persuasion," Brown "stirs the deepest conflict ... in testing the thesis I propose." Wechsler, "Toward Neutral Principles," 31.

120 Ibid., 27. 
mula was not overruled 'in form' but was held to have 'no place' in public education on the ground that segregated schools are 'inherently unequal,' with deleterious effects upon the colored children in implying their inferiority, effects which retard their educational and mental development." 121 For Wechsler, the Court's judgment in Brown appeared to rest on the facts found by the district court-which provided an uncertain and contingent basis for the decision. ${ }^{122}$

Wechsler ultimately found it "hard to think the judgment [in Brown] really turned upon the facts" in the case, and located its foundational principle in "the view that racial segregation is, in principle, a denial of equality to the minority against whom it is directed; that is, the group that is not dominant politically and, therefore, does not make the choice involved." ${ }^{123}$ However, this principle was not persuasive for Wechsler, because the problem posed by segregated schools was not discrimination, but denial of freedom of association. ${ }^{124}$ And here a sufficiently neutral principle became elusive, because "if the freedom of association is denied by segregation, integration forces an association upon those for whom it is unpleasant or repugnant." 125 For Wechsler, the challenge posed by Brown was the inability to articulate "a basis in neutral principles" for the decision. ${ }^{126}$

\section{Conclusion}

The brevity of this article underscores its limits. I have addressed an enormously broad topic, and along the way I have tried to qualify my argument. Each author is as representative as a single author may be with respect to a particular legal philosophy. Of course, to articulate that notion is to demonstrate its limitations. Furthermore, it is difficult, if not impossible, to determine the exact causal relationship between a historical eventespecially one as complex as the Nuremberg trials-and its effect on a school of legal thought. Nevertheless, the trials both reflected and shaped

121 Ibid., 32.

122 The uncertainty derived from Wechsler's questions about what exactly the record in the district court demonstrated, while the contingency was due to the limited applicability to the next case of the findings by the district court in the Topeka, Kansas, case. Ibid., 32-33.

123 Ibid., 33.

124 See ibid., 33-34.

125 See ibid., 34.

126 Ibid. 
post-war concerns about the threat of totalitarianism and the future of democracy. These concerns, in turn, were reflected in the decline of legal realism, the revival of natural law, and the emergence of legal process philosophy.

As much as this article has emphasized historical context in understanding the jurisprudential developments it describes, it is worth noting the enduring contribution made by each author in legal thought. Frank's emphasis on the psychological need for certainty in Law and the Modern Mind to explain the function of the law and the operation of the legal system has not fared well over time. Nevertheless, his emphasis on the fact-finding process remains relevant today in, for example, the growth of clinical programs at law schools. Fuller's debate with Hart is a philosophical exchange for the ages, and Fuller's case for secular natural law theory continues to be taught today in jurisprudence classes. And of the many contributions to legal thought made by Wechsler, perhaps none is as well-known as his Neutral Principles article; its preoccupation with demarcating a principled line between law and politics informs the most pressing constitutional law questions of our time. 
